\title{
曲げ剛性を考慮したケーブルの面内線形自由振動*

\author{
FREE IN-PLANE VIBRATION OF A CABLE \\ WITH BENDING RIGIDITY
}

\author{
山口宏 樹**.宮田利 雄*** ・伊藤 学**** \\ By Hiroki YAMAGUCHI, Toshio MIYATA and Manabu ITO
}

\section{1.はじめに}

ケーブルはその径に比べて十分細い素線の集合体であ って，その変形，および対応する剛性は大変に複雑であ るが, 曲げ剛性，およびねじれ剛性は全般に小さく，構 造システム全体に㧍けるケーブルの挙動を問題とすると きにはそれらを無視し, 引張材として扱らのが普通であ る.しかし，このようにケーブルを材軸引張力のみによ って力の伝達される部材, つまり完全可暁性を有する 1 次元部材として扱らことに対して十分な検討がなされて いるわけではなく，曲げ剛性を無視したことによる影響 がどの程度なのかははっきりしていないのが現状であろ う.また，近年ケーブル部材の適用範囲は拡大され，た とえばプレストレストコンクリート斜張橋の斜張ケーブ ル, 下路アーチ橋の吊材等, 径に比して長さの短い使わ れ方も少なくないため, 曲げ剛性が有意となる場合がい かなる場合であるかを知っておく必要があるように思わ れる.とはいってもケーブルは引張材としての機能を十 分に活用する部材であるわけで, フレキシブルであるこ とに変わりはなく，その動的問題が設計上重みを占める と考えられる.したがってケーブルの曲げ抵抗がその挙 動にどの程度影響するかを知っておくことは，特にケー ブルの動特性を論ずるうえで検討しておくべき問題であ るといえる.

このような観点から，本論文では曲げ抵抗がケーブル の固有振動特性にいかに影響するかを論ずる．ケーブル はその曲げ剛性が無視し得ないとしてもやはりフレキシ ブルな部材を意味し, ケーブルの動特性としては 3 次元

* 本論文は, 第 26 回構造工学シンポジウムにおける論文 ${ }^{1)}$ に固有振動解析法执よび数值パラメーター解析 (パラメ ーターの追加）を加え, まとめたものである.

** 正会員 工博 東京大学講師 工学部土木工学科

*** 正会員 工博 横浜国立大学教授 工学部土木工学科

**** 正会員 工博 東京大学教授 工学部土木工学科
空間での挙動を問題とすべきであるが，その扱いは大変 に複雑となるため本論文では面内問題に限定している. まず，ケーブルを伸び，曲げ 2 方向，㸚じれの 4 つの変 形パラメーターを有する充実断面 1 次元部材として考え たときの基礎方程式から，面内曲げ振動の支配方程式を 導く．そして，最も基本的な動特性としての面内線形固 有振動特性について, 断面の伸び岡性, 曲げ剛性, およ び問題とする現象の代表長によって定義する曲げ抵抗比 が, 固有振動数, および固有モードに及ぼす影響を数值 パラメーター解析によって示す.

曲げ剛性を考慮したケーブルの動特性に関する研究と しては弦について固有振動数に及ぼす曲げ剛性の影響を 扱った Ramberger の研究 ${ }^{2)}$, 偏平ケーブルのそれを扱 った Bauer の研究 ${ }^{3}$ ，そして振動法によるケーブル張力 算定問題に関連した新家らの研究 ${ }^{4} か ゙$ 挙げられる. 特に 新家らの研究はケーブル張力の実用算定式に着目してい るものの, 実験および有限要素法による固有振動解析に より曲げ剛性がケーブルの固有振動数と張力との関倸に 及ぼす影響を明らかにしており興味媣い。また曲げ剛性 を考慮したケーブルの運動は結局はアーチと同様の支配 方程式で表わされ，軸力の作用が逆ではあるもののケー ブルの動特性は基本的にはアーチのそれと類似してお り, アーチの面内自由振動解析に 関する数多くの研究 ${ }^{5)}$ から曲げ剛性を考慮したケーブルの線形固有振動特性の 推定がある程度可能であるといえよう．このようなこと を踏まえたらえで, 本論文は完全可暁性を仮定したケー ブルの 3 次元線形自由振動特性に関する著者らの研究6) と対応させるべく，ケーブルの動特性を支配する 3 つの 無次元パラメーター,つまりサグ比, 支点間傾斜角, お よび伝播速度比で整理した面内線形自由振動特性につい て曲げ抵抗の影響を明らかにするものである。

なお, ケーブルの曲げ剛性はケーブルが素線の集合体 であるがために普通の棒材のよらにヤング率と断面性状 とから一義的に決定され得るものではなく，実験的にも 
データがあまり得られていないのが現状であるが，本論 文では簡単のためケーブルを均質な曲線棒として扱い， その換算剛性が与えられるものとして考えている.

\section{2. 曲げを考虑したケーブルの支配方程式}

\section{（1）軸力，曲げ，およびねじりを受ける 1 次元部材}

ケーブルを軸力，曲げ，およびねじりを受ける1 次元 部材として考え，次のような仮定を設ける.

（i）ケーブルの断面は平面を保持する.

(ii） ケーブル断面には面内ひずみは生じない.

（iii） せん断変形，抢よび曲げによる同転慣性は無視 する。

（iv）ねじりに関しては St. Venant のねじりのみを 考える.

（v）ひずみは 1 に対して十分小さな微小ひずみとす る.

仮定（i)〜 (iii) はケーブルの断面寸法が部材長に比べて 十分に小さい場合に設定され得るものであるが，波動を 論ずる場合には仮定（iii）による誤差が大きくなり得る ことに注意する必要がある，また，仮定 (iv) はケーブ ルを円形に近い充実断面の棒として扱うことによるもの である。

図一1 に示すように，任意時刻におけるケーブル重心 軸は滑らかな空間曲線で与えられるものとし，その重心 線の位置を空間に固定した右手系直交単位べクトル $\boldsymbol{i}_{1}$, $\boldsymbol{i}_{2}, \boldsymbol{i}_{3}$ で分解した成分 $\left\{x^{1}, x^{2}, x^{3}\right\}$ で規定するものとす る.一方, 任意時刻でのケーブル重心線に沿ら長さで定 義する曲線座標（物体固定座標）を $s$ とすれば, 任意時 刻 $t$ におけるケーブル重心線上の状態量はパラメーター $s ， お よ ひ ゙ ~ t$ を独立変数として表わされる.

また，ケーブル重心線上の任意点での単位接線ベクト ル, 単位法線ベクトル, および単位倍法線ベクトルをそ れぞれ $\lambda, \mu, \nu$ で表わす.

さらに重心軸に直角な断面の主軸 2 方向に重ねて直交

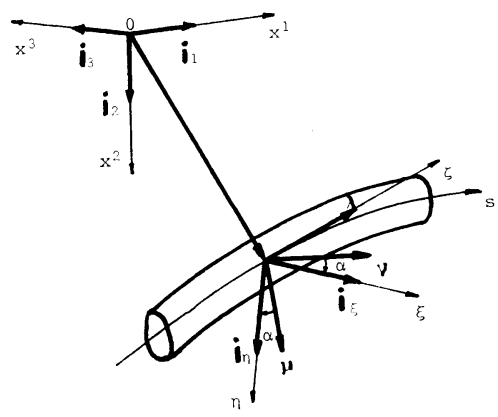

图一1 座 標 系
直線座標 $\xi, \eta$ を定め, 重心軸に沿う曲線座標 $s$ を $\{\xi$, $\eta, s\}$ が右手系となるように選んで物体固定座標を定義 する. その単位基ベクトルを $\boldsymbol{i}_{\xi}, \boldsymbol{i}_{\eta}, \boldsymbol{i}_{\zeta}$ とし，ケーブル 断面のねじれ回転を規定するパラメーター $\alpha を$ 図一1 の ように導入する.

以上のような座標系を用い，前述の仮定のもとに爫一 ブルの支配方程式を求めると次のようになる ${ }^{11,7)}$.

(i) 運動方程式

(たわみ振動)

$$
\begin{array}{r}
\frac{\partial}{\partial s}\left(\frac{Q_{\nu}}{\kappa} e_{i j k} \frac{\partial^{2} x^{j}}{\partial s^{2}} \frac{\partial x^{k}}{\partial s}+\frac{Q_{\mu}}{\kappa} \frac{\partial^{2} x^{i}}{\partial s^{2}}+T \frac{\partial x^{i}}{\partial s}\right) \\
-\rho \frac{\partial^{2} x^{i}}{\partial t^{2}}+\bar{X}^{i}=0 \quad i=1,2,3 \cdots \cdots \cdots(1 \cdot \mathrm{a})
\end{array}
$$

（㸚じれ振動）

$$
\frac{\partial M_{T}}{\partial s}-\kappa M_{n}-m \frac{\partial^{2} \Theta}{\partial t^{2}}=0
$$

(ii) 断面力-変形関係式

$$
\begin{aligned}
& M_{\nu}=-\left(E I_{\xi} \kappa \cos ^{2} \alpha+E I_{\eta} \kappa \sin ^{2} \alpha\right) \quad \cdots \cdots(2 \cdot \mathbf{a}) \\
& M_{\mu}=\left(-E I_{\xi}+E I_{\eta}\right) \kappa \sin \alpha \cos \alpha \quad \cdots \cdots \cdots(2 \cdot \mathrm{b}) \\
& M_{T}=E J\left(\frac{\partial \alpha}{\partial s}+\tau\right) \cdots \cdots \cdots \cdots \cdots \cdots \cdots \cdots \cdots \cdots \cdots \cdots \cdots \cdots \cdots(2 \cdot \mathrm{c}) \\
& Q_{\nu}=-\left(\frac{\partial M_{\mu}}{\partial s}+\tau M_{\nu}+\kappa M_{T}\right) \cdots \cdots \cdots \cdots(2 \cdot \mathrm{d}) \\
& Q_{\mu}=\frac{\partial M_{\nu}}{\partial s}-\tau M_{\mu} \cdots \cdots \cdots \cdots \cdots \cdots \cdots \cdots \cdots \cdots \cdots \cdots \cdots \cdots \cdots(2 \cdot \mathrm{e}) \\
& T=E A
\end{aligned}
$$

(iii) 変形-変位関係式

$$
\begin{aligned}
& (1+\epsilon)^{2}=\frac{\partial x^{j}}{\partial s_{0}} \cdot \frac{\partial x^{j}}{\partial s_{0}} \\
& \kappa^{2}=\frac{\partial^{2} x^{j}}{\partial s^{2}} \cdot \frac{\partial^{2} x^{j}}{\partial s^{2}} \\
& \tau=\frac{1}{\kappa^{2}} e_{i j k} \frac{\partial x^{i}}{\partial s} \cdot \frac{\partial^{2} x^{j}}{\partial s^{2}} \cdot \frac{\partial^{3} x^{k}}{\partial s^{3}} \\
& \frac{\partial \Theta}{\partial s}=\frac{\partial \alpha}{\partial s}+\tau
\end{aligned}
$$

ここで, $Q_{\nu}, Q_{\mu}$ はせん断力を $\boldsymbol{\nu}, \boldsymbol{\mu}$ で分解した成分, $T$ は軸力 (ケーブル張力), また $M_{\nu}, M_{\mu}$ は曲げモーメン トを $\boldsymbol{\nu}, \boldsymbol{\mu}$ で分解した成分， $M_{T}$ はねじりモーメントで ありそれぞれケーブルの断面力である. また， $\epsilon, \kappa, \tau$ はそれぞれケーブル重心線の伸び率，曲率，およびねじ れ率であり， $\rho$ および $m$ はケーブルの単位長さ当たり 質量抢よび極慣性モーメント， $E I_{\xi}, E I_{\eta}$ はケーブル主 軸 2 方向の曲げ剛性, $E J$ はねじれ剛性, $E A$ は伸び剛 性であり, $\bar{X}^{i}$ は分布外力成分である. さらに, $\Theta$ はケ ーブルのねじれ角であって，式 $(3 \cdot \mathrm{d})$ よりわかるよう にねじれパラメーター $\propto$ のみならず, 空間位置 $\left\{x^{1}, x^{2}\right.$, $\left.x^{3}\right\}$ にも関係する.

なお， $s_{0}$ は無応力状態のケーブルの重心線に沿ら長さ で定義する曲線座標を意味し，添字については総和規約 に従うものとする. 


\section{（2）面内曲げ問題}

ケーブルは初期状態において $\boldsymbol{i}_{1}-\boldsymbol{i}_{2}$ 面内に静止してい るものとし,$i_{3}$ 方向への変位は $i_{1}, i_{2}$ 方向の変位に影響 することなく拘束されているものとする.さらにねじれ 剛性 $E J$ を無視し, ねじれに関するパラメーター り除くと, 面内曲げ問題の支配方程式が次のように導か れる.

(i) 運動方程式

$$
\begin{gathered}
\frac{\partial}{\partial s}\left(\frac{\partial M}{\partial s} \frac{1}{\kappa} \frac{\partial^{2} x^{i}}{\partial s^{2}}+T \frac{\partial x^{i}}{\partial s}\right) \\
-\rho \frac{\partial^{2} x^{i}}{\partial t^{2}}+\bar{X}^{i}=0 \quad i=1,2
\end{gathered}
$$

(ii) 断面力-変形関係式

$$
T=E A \epsilon, M=-E I \kappa
$$

(iii) 変形-変位関係式

$$
(1+\epsilon)^{2}=\frac{\partial x^{j}}{\partial s_{0}} \cdot \frac{\partial x^{j}}{\partial s_{0}}, \kappa^{2}=\frac{\partial^{2} x^{j}}{\partial s^{2}} \cdot \frac{\partial^{2} x^{j}}{\partial s^{2}}
$$

なお, 式 (4) は一般的なアーチ (曲線棒) の面内曲げに 関する運動方程式として知られている ${ }^{5)}$.

\section{3. 面内線形自由振動に及ぼす曲げ抵抗の影響}

\section{（1）面内線形自由振動の支配方程式}

あるつり合い状態を基準状態とし, そこからの外力の 微小増分, あるいは変位の微小増分を考え, それらによ るつり合い状態の変化を表わす線形化された支配方程 式, すなわち増分形の支配方程式を導く. 変位, 断面 力, 変形, 外力の各增分量を $\delta$ を付して表わすものとす れば, 式 (4) から増分形の運動方程式として次式が得 られる。

$$
\begin{aligned}
& \frac{\partial}{\partial s}\left\{\frac{\partial \delta M}{\partial s} \frac{1}{\kappa} \frac{\partial^{2} x^{i}}{\partial s^{2}}+\frac{\partial M}{\partial s} \delta\left(\frac{1}{\kappa} \frac{\partial^{2} x^{i}}{\partial s^{2}}\right)\right. \\
& \left.+\delta T \frac{\partial x^{i}}{\partial s}+T \frac{\partial \delta x^{i}}{\partial s}\right\}-\rho \frac{\partial^{2} \delta x^{i}}{\partial t^{2}}+\delta \bar{X}^{i}=0 \\
& i=1,2
\end{aligned}
$$

また式 $(5 \cdot a, b)$ から增分形の断面力一変形関倸式は，

$$
\begin{aligned}
& \delta T=E A \delta \leftarrow \cdots \\
& \delta M=\cdots E I \delta \kappa
\end{aligned}
$$

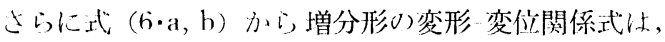

$$
\begin{aligned}
& \partial \epsilon=\frac{1}{1+\epsilon} \frac{\partial x^{j}}{\partial s_{0}} \frac{\partial \delta x^{j}}{\partial s_{0}} \fallingdotseq \frac{\partial x^{j}}{\partial s_{0}} \frac{\partial \delta x^{j}}{\partial s_{0}} \cdots(9 \cdot \mathrm{a}) \\
& \delta \kappa=\frac{1}{\kappa} \frac{\partial^{2} x^{j}}{\partial s^{2}} \frac{\partial^{2} \delta x^{j}}{\partial s^{2}} \cdots \cdots \cdots \cdots \cdots \cdots \cdots \cdots(9 \cdot \mathrm{b})
\end{aligned}
$$

したがって式 $(9 \cdot a, b)$ を式 $(8 \cdot a, b)$ に代人して断 面力増分を変位増分で表わし, さらにそれを増分形運動 方程式 (7) に代入すれば, 変位表示の増分形支配方程
式が次のように導かれる.

$$
\begin{aligned}
& \rho \frac{\partial^{2} \delta x^{i}}{\partial t^{2}}+E I \frac{\partial}{\partial s}\left[\left(\frac{1}{\kappa^{2}} \frac{\partial^{2} x^{k}}{\partial s^{2}} \frac{\partial^{3} x^{k}}{\partial s^{3}}\right) \frac{\partial^{2} \delta x^{i}}{\partial s^{2}}\right. \\
& +\left\{\frac{1}{\kappa^{2}} \frac{\partial^{2} x^{i}}{\partial s^{2}}\left(\frac{\partial^{3} x^{j}}{\partial s^{3}}-\frac{2}{\kappa^{2}} \frac{\partial^{2} x^{k}}{\partial s^{2}} \frac{\partial^{3} x^{k}}{\partial s^{3}} \frac{\partial^{2} x^{j}}{\partial s^{2}}\right)\right\} \\
& \left.\cdot \frac{\partial^{2} \delta x^{j}}{\partial s^{2}}+\left(\frac{1}{\kappa^{2}} \frac{\partial^{2} x^{i}}{\partial s^{2}} \frac{\partial^{2} x^{j}}{\partial s^{2}}\right) \frac{\partial^{3} \delta x^{j}}{\partial s^{3}}\right] \\
& -E A \frac{\partial}{\partial s}\left\{\epsilon \frac{\partial \delta x^{i}}{\partial s}+\left(\frac{\partial x^{i}}{\partial s_{0}} \frac{\partial x^{j}}{\partial s_{0}}\right) \frac{\partial \delta x^{j}}{\partial s_{0}}\right\}=\delta \bar{X}^{i} \\
& i=1,2
\end{aligned}
$$

ここで基準状態として静的につり合った初期状態をと り, その位置からの微小振動を考えれば, 増分形の線形 化された支配方程式から面内線形振動の支配方程式が導 かれる。

ケーブルは初期状態において $x-y$ 面内（鉛直面内）に 静止しているものとし, そのつり合い形状を $\left(x_{e}, y_{e}\right)$ で表わす. またそのつり合い位置からの動的変位を（u， v）で表わすものとする.つまり，

$$
\begin{aligned}
& x^{1}=x_{e}\left(s_{e}\right), x^{2}=y_{e}\left(s_{e}\right) \cdots \cdots \cdots \cdots \cdots(11 \cdot \mathrm{a}, \mathrm{b}) \\
& \delta x^{1}=u\left(s_{e}, t\right), \delta x^{2}=v\left(s_{e}, t\right) \cdots \cdots \cdots \cdots(12 \cdot \mathrm{a}, \mathrm{b})
\end{aligned}
$$

上する.ここで $s_{e}$ は初期状態でのケーブル重心線に沿 う長さで定義する曲線座標である. 式 $(11 \cdot a, b),(12 \cdot$ a，b）を式（10）に代入し，外力を 0 として整理すれば, 曲げ抵抗を考慮したケーブルの面内線形自由振動に関す る支配方程式が次のように導かれる.

$$
\begin{aligned}
& \frac{\partial^{2} u}{\partial t^{2}}-\frac{\partial}{\partial s_{e}}\left[\left(c_{0}^{2} \frac{1}{x_{e}{ }^{\prime}}+c_{1}^{2} x_{e}{ }^{2}\right) \frac{\partial u}{\partial s_{e}}\right. \\
& -c_{2}{ }^{2} \frac{1}{\kappa^{2}}\left\{2 x_{e}{ }^{\prime \prime} x_{e}{ }^{\prime \prime \prime}+y_{e}^{\prime \prime} y_{e}{ }^{\prime \prime \prime}\right. \\
& \left.-\frac{2}{\kappa^{2}}\left(x_{e}^{\prime \prime} x_{e}^{\prime \prime \prime}+y_{e}^{\prime \prime} y_{e}^{\prime \prime \prime}\right) x_{e}{ }^{\prime \prime 2}\right\} \frac{\partial^{2} u}{\partial s_{e}{ }^{2}} \\
& \left.-c_{2}^{2} \frac{1}{\kappa^{2}} x_{e}{ }^{\prime \prime 2} \frac{\partial^{3} u}{\partial s_{e}^{3}}\right] \\
& -\frac{\partial}{\partial s_{e}}\left[c_{1}^{2} x_{e}{ }^{\prime} y_{e}{ }^{\prime} \frac{\partial v}{\partial s_{e}}-c_{2}{ }^{2} \frac{1}{\kappa^{2}} x_{e}{ }^{\prime \prime}\left\{y_{e}{ }^{\prime \prime \prime}\right.\right. \\
& \left.-\frac{2}{\kappa^{2}}\left(x_{e}^{\prime \prime} x_{e}{ }^{\prime \prime \prime}+y_{e}{ }^{\prime \prime} y_{e}{ }^{\prime \prime \prime}\right) y_{e}{ }^{\prime \prime}\right\} \frac{\partial^{2} v}{\partial s_{e}{ }^{2}} \\
& \left.-c_{2}^{2} \frac{1}{\kappa^{2}} x_{e}{ }^{\prime \prime} y_{e}{ }^{\prime \prime} \frac{\partial^{3} v}{\partial s_{e}^{3}}\right]=0 \\
& \frac{\partial^{2} r^{\prime}}{\partial t^{2}}-\frac{\partial}{\partial s_{e}} \mid\left(c_{0}^{2} \frac{1}{x_{e}^{\prime}}+c_{1}^{2} v_{c}^{2}\right) \frac{\partial v}{\partial s_{c}} \\
& \cdots c_{2}^{2} \frac{1}{\kappa^{2}}\left\{x_{c}{ }^{\prime \prime} \cdot x_{c}{ }^{\prime \prime \prime}+2 y_{c}{ }^{\prime \prime} y_{c}^{\prime \prime \prime}\right. \\
& \left.-\frac{2}{\kappa^{2}}\left(x_{e}^{\prime \prime} x_{e}^{\prime \prime \prime}+y_{e}^{\prime \prime} y_{e}^{\prime \prime \prime}\right) y_{e}^{\prime \prime 2}\right\} \frac{\partial^{2} v}{\partial s_{e}^{2}} \\
& \left.-c_{2}{ }^{2} \frac{1}{\kappa^{2}} y_{e}{ }^{\prime \prime 2} \frac{\partial^{3} v}{\partial s_{e}^{3}}\right] \\
& -\frac{\partial}{\partial s_{e}}\left[c_{1}^{2} x_{e}{ }^{\prime} y_{e} \frac{\partial u}{\partial s_{e}}-c_{2}^{2} \frac{1}{\kappa^{2}} y_{e}^{\prime \prime}\left\{x_{e}{ }^{\prime \prime \prime}\right.\right.
\end{aligned}
$$




$$
\begin{aligned}
& \left.-\frac{2}{\kappa^{2}}\left(x_{e}{ }^{\prime \prime} x_{e}{ }^{\prime \prime \prime}+y_{e}{ }^{\prime \prime} y_{e}{ }^{\prime \prime \prime}\right) x_{e}{ }^{\prime \prime}\right\} \frac{\partial^{2} u}{\partial s_{e}{ }^{2}} \\
& \left.-{c_{2}}^{2} \frac{1}{\kappa^{2}} x_{e}{ }^{\prime \prime} y_{e}{ }^{\prime \prime} \frac{\partial^{3} u}{\partial s_{e}{ }^{3}}\right]=0 \cdots \cdots \cdots(13 \cdot
\end{aligned}
$$

ただし，

$$
\begin{aligned}
& c_{0}{ }^{2}=\frac{H_{e}}{\rho}, c_{1}{ }^{2}=\frac{E A}{\rho}, c_{2}{ }^{2}=\frac{E I}{\rho} \cdots \cdots(14 \cdot \mathrm{a}, \mathrm{b}, \mathrm{c}) \\
& H_{e}=\frac{E A \epsilon}{x_{e}{ }^{\prime}}
\end{aligned}
$$

であり, $c_{0}$, および $c_{1}$ は弦の横波, および縦波の伝播速 度である.また'は $s_{e}$ に関する常微分を意味し, 式 $(13 \cdot \mathrm{a}, \mathrm{b})$ を導くにあたっては微小ひずみの仮定から $d s$ $\fallingdotseq d s_{e} \fallingdotseq d s_{0}$ としている.

なお, 式 $(13 \cdot a, b)$ で—— 部が曲げ剛性を考慮した ことによる付加項で，これを無視すれば完全可㧥性ケー ブルの面内線形自由振動の支配方程式 ${ }^{6)}$ と一致する.

\section{（2）固有振動解析}

ケーブルの曲げ岡性を考慮した場合，境界条件の固有 振動特性に及ぼす影響は大きいと考えられ，前述の Ramberger $^{2)}$, Bauer ${ }^{3)}$ の研究においてもその点に注意 を払い，いくつかの境界条件について考察が加えられて いる.このように曲げ剛性を考虑したケーブルの動特性 を考える場合, 境界条件は一つのパラメーターとして重 要なものとなるが本論文では完全可暁性ケーブルとの対 応を考え, 境界条件の影響の入らない両端ピン支持の場 合を考えた. このときこの境界条件を考慮して面内線形 自由振動の解を次のような級数に展開する.

$$
\begin{aligned}
& u\left(s_{e}, t\right)=\sum_{i=1}^{\infty} p_{x}{ }^{i}(t) \sin \frac{i \pi s_{e}}{l^{*}} \\
& v\left(s_{e}, t\right)=\sum_{i=1}^{\infty} p_{y}{ }^{i}(t) \sin \frac{i \pi s_{e}}{l^{*}}
\end{aligned}
$$

ここで $p_{x}{ }^{i}, p_{y}{ }^{i}$ は $x, y$ 方向の一般化変位, $l^{*}$ は初期 ケーブル長である. 長さ $l^{*}$ の弦, あるいは単純はりの $n$ 次基準関数は $\sin \frac{n \pi s_{e}}{l^{*}}$ であるから, 式 $(16 \cdot \mathrm{a}, \mathrm{b})$ は 曲げを考慮したケーブルの固有振動を弦, あるいは単純 はりの基淮関数で展開することを意味する.

式 (16 a a b) を支配方程式 (13・a, b) に代入して Galerkin 法を適用する. さらに適当な 無次元化を行え ば次式を得る。

$$
\begin{aligned}
\frac{1}{\frac{\pi^{2}}{l^{2}} c_{0}{ }^{2} \cos \theta} \ddot{p}_{x}^{j} & +\sum_{i=1}^{\infty}\left[\frac{2 i j}{\sigma_{l}^{3} \cos \theta} I_{1} *+\frac{2 i^{2} j \pi}{\sigma_{l}{ }^{4} \cos \theta} r k^{2} I_{2} *\right. \\
& \left.+\frac{2 i^{3} j \pi^{2}}{\sigma_{l}{ }^{5} \cos \theta} r k^{2} I_{3} *\right] p_{x}{ }^{i} \\
& +\sum_{i=1}^{\infty}\left[\frac{2 i j}{\sigma_{l}^{3} \cos \theta} k^{2} I_{4}^{*}+\frac{2 i^{2} j \pi}{\sigma_{l}{ }^{4} \cos \theta} r k^{2} I_{5} *\right. \\
& \left.+\frac{2 i^{3} j \pi^{2}}{\sigma_{l}{ }^{5} \cos \theta} r k^{2} I_{8} *\right] p_{y}{ }^{i}=0
\end{aligned}
$$

$$
\begin{aligned}
\frac{1}{\frac{\pi^{2}}{l^{2}} c_{0}{ }^{2} \cos \theta} \ddot{p}_{y}{ }^{j} & +\sum_{i=1}^{\infty}\left[\frac{2 i j}{\sigma_{l}^{3} \cos \theta} I_{7} *+\frac{2 i^{2} j \pi}{\sigma_{l}{ }^{4} \cos \theta} r k^{2} I_{8}{ }^{*}\right. \\
& \left.+\frac{2 i^{3} j \pi^{2}}{\sigma_{l}{ }^{5} \cos \theta} r k^{2} I_{9} *\right] p_{y}{ }^{i} \\
& +\sum_{i=1}^{\infty}\left[\frac{2 i j}{\sigma_{l}^{3} \cos \theta} k^{2} I_{4}{ }^{*}+\frac{2 i^{2} j \pi}{\sigma_{l}{ }^{4} \cos \theta} r k^{2} I_{10} *\right. \\
& \left.+\frac{2 i^{3} j \pi^{2}}{\sigma_{l}{ }^{5} \cos \theta} r k^{2} I_{6}{ }^{*}\right] p_{x}{ }^{i}=0 \quad j=1,2, \cdots
\end{aligned}
$$

ここで, $l$ はスパン長, $\theta$ は支点間傾斜角, $\sigma_{l}$ は無次元 ケーブル長 $\left(=l^{*} / l\right), k$ は伝播速度比 $\left(=c_{1} / c_{0}\right)$ で,.$\cdot$ は時間 $t$ に関する 2 階常微分を意味する. また $I_{1}{ }^{*} \sim I_{10} *$ は Galerkin 法による積分項で初期形状に依存する無次 元定数である (補遺). さらに $r$ は曲げ抵抗を考虑した ことにより生ずる無次元パラメーターで, 次式で表わさ れる.

$$
r=\frac{E I}{l^{2}} / E A
$$

ここではこの $r$ を曲げ抵抗比とよぶことにする.

式 $(17 \cdot a, b)$ において級数を有限項で打ち切り, マト リックス表示すれば,

$$
\frac{1}{\frac{\pi^{2}}{l^{2}} c_{0}{ }^{2} \cos \theta}[I]\{\ddot{p}\}+[A]\{p\}=\{0\}
$$

ここで, $\{p\}$ は一般化変位ベクトル, $[I]$ は単位マトリ ックス, $[A]$ は係数マトリックスである.

式（19）に $\{p\}=\{\varphi\} \exp (\boldsymbol{i} \omega t)(i$ : 虚数単位) を代入 すれば，

$$
\left[[A]-\frac{\omega^{2}}{\frac{\pi^{2}}{l^{2}} c_{0}^{2} \cos \theta}[I]\right]\{\varphi\}=\{0\}
$$

となる. したがって $[A]$ の固有值として無次元固有振 動数 $\omega^{*}$ が求まる. $\omega^{*}$ 注固有振動数 $\omega$ を弦の基本振動 数 $\frac{\pi}{l} c_{0} \sqrt{\cos \theta}$ で無次元化したものである.

\section{（3） 解析結果，および考察}

ケーブルの初期形状をカテナリーとして与え数值パラ メーター解析を行った．計算にはすべて 10 項までの級 数近似を用いたが, 級数項数については完全可泋性ケー ブルの場合の考察 ${ }^{6}$ から 10 項である程度の精度が得ら れるものと判断した.

a) モード形依存性

$k^{2}=900, \theta=0^{\circ}$ の場合, $r=10^{-7}, 0.026,0.1$ の各サ グ比を有するケーブルの低次 5 つの固有振動数 $\omega^{*}$ につ いて, 曲げ抵抗比 $r$ 影響をみたものが 図一2 である. 横軸が曲げ抵抗比 $r$, 縦軸は完全可挩性ケーブルの固有 振動数 $\omega_{0}{ }^{*}$ との差を $\omega_{0}{ }^{*}$ で無次元化した百分率 : $\left\{\left(\omega^{*}\right.\right.$ $\left.\left.-\omega_{0}^{*}\right) / \omega_{0}^{*}\right\} \times 100(\%)$ で, 両軸とも対数目盛である. 


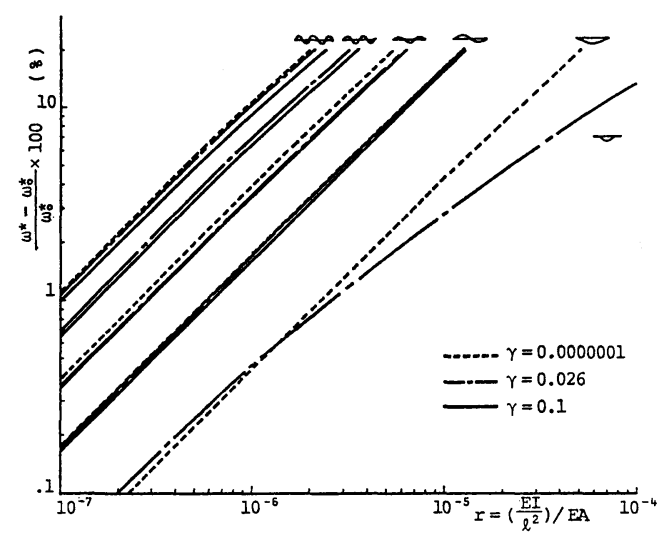

図一2 曲げ抵抗比に対する固有振動数の変化 $\left(k^{2}=900, \theta=0^{\circ}\right)$

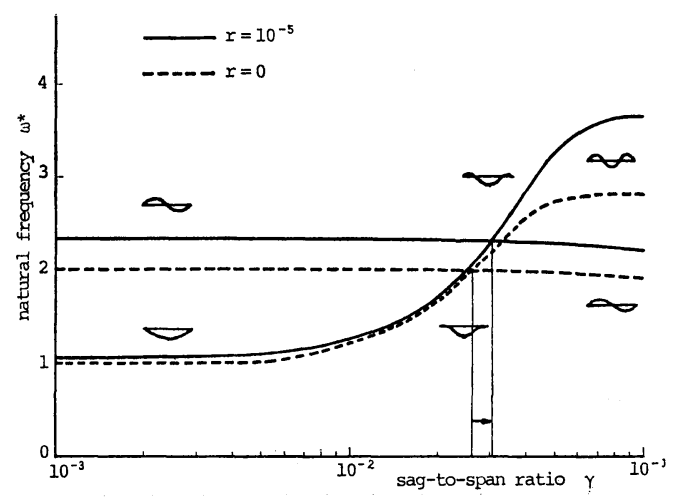

図-3 サグ比に対する固有振動数の変化 $\left(k^{2}=900, \theta=0^{\circ}\right)$

図一2で $r$ を固定し，各次振動数への曲げ抵抗の影響に 着目すると，曲げを考虑したケーブルの固有振動数 $\omega^{*}$ は完全可暁性ケーブルの振動数 $\omega_{0}^{*}$ より大きく，その 差は振動モードの曲率変化の多い高次振動ほど大きいこ とがわかる.しかもその度合はサグ比に依存していな い. また $r$ を変化させた場合の固有振動数の変化率に着 目すると, $r=0.026$ の場合の 1 次振動を除いて, 振動 次数, サグ比によらずほぼ一定であることがいえる.

図一3 には $r=10^{-5}$ の場合の固有振動数曲線（サグ比 に対する固有振動数の変化）を完全可接性ケーブルの場 合のそれとともに示した. これをみると, 対称モードに 対态する固有振動数 $\omega^{*}$ では, 少グ比の増加に伴ったモ 一ド形の遷移によって曲げ抵抗の影響が次第に大きくな っている．ただ，モード遷移領域内のサグ比では逆に曲 げ抵抗の影響は小さい. 一方, 逆対称モードではサグ比 に依存せずに曲げ抵抗の影響はほぼ一定である。その結 果, 固有振動数曲線の交点が曲げを考慮したことによっ てサグ比の大きな方へと移動している.したがって，モ 一ド遷移領域内のサグ比 $(r=0.026$ はその一例 $)$ の場 合には, 曲げ抵抗比 $r$ の増加に伴ってモード形の変化し

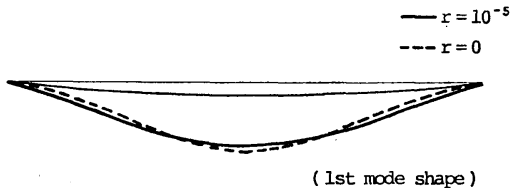

(a) $\mathrm{k}^{2}=900, \theta=0^{\circ}, \gamma=0.026$

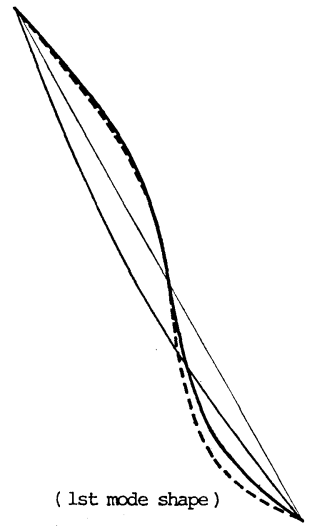

(b) $k^{2}=900, \theta=60^{\circ}, y=0.2$
ていることが考えられ，モード形が一定と考えられる $r=10^{-7}, 0.1$ の場合と違った変化率を 図一2 で示してい るといえる. 実際モード形を見てみると， $r=10^{-7}, 0.1$ の場合にはほとんど差がないのに対し， $r=0.026$ の場 合には図一4（a）に示すように曲げ抵抗を考慮したケー ブルのモード形の方が完全可接性ケーブルのそれより曲 率変化が少なくなっている.

一方, 傾斜ケーブルの場合 $\left(\theta=60^{\circ}\right)$, 完全可暁性ケー ブルではサグ比の増加に伴らモード形の遷移がどの振動 次数に対しても認められる. モード遷移領域内のサグ比 を有するケーブルでは曲げ抵抗比 $r$ の増加に伴ってモー ド形の変化することが考えられるから, 固有振動数 $\omega^{*}$ の $r$ に対する変化率はサグ比, および振動次数によって 変化する (図一5, 6). 実際 図一4 (b) に示すように, r $=0.2$ の場合のモード形は 1 次, 2 次雨振動とも, 曲げ 抵抗を考慮した場合に曲率変化が少なくなる方向にかな

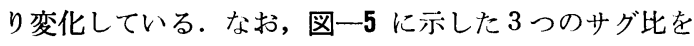
有するケーブルは各次振動でモード形が少しずつ異なる ため, 水平ケーブルの場合の 図一2のように各振動次数 での曲げ効果がサグ比に依存しないということはない. また, 水平ケーブルの場合と比較して曲げ抵抗の影響が 小さいのは, 同スパンの傾斜ケーブルの方が支点間距離 が長くなることによるといえる.

b）初期張力依存性 


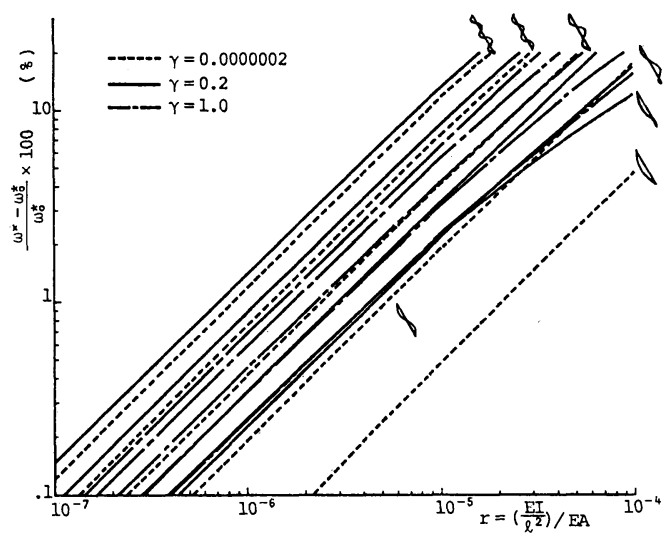

図一5 曲げ抵抗比に対する固有振動数の変化 $\left(k^{2}=900, \theta=60^{\circ}\right)$

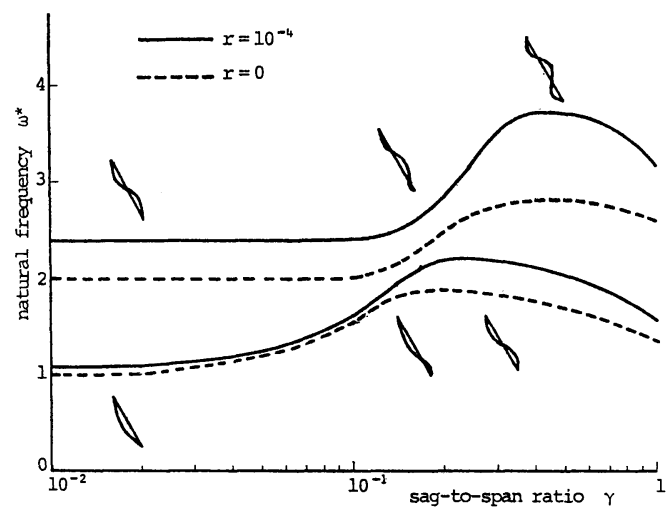

図一6 サグ比に対する固有振動数の変化 $\left(k^{2}=900, \theta=60^{\circ}\right)$

曲げを考慮したケーブルのたわみに対する剛性は，線 形理論では曲げ抵抗パラメーター $E I / l^{2}$, 伸び剛性 $E A$, それに初期水平張力 $H_{e}$ によって決定される. したがっ て曲げ抗抵の影響柱初期水平張力を表わす無次元パラメ 一ター $k^{2}$ (伝播速度比 $k$ の 2 乗, つまり伸び剛性一水平 張力比）にも依存するであろらことが予想される.

$k^{2}=4000, \theta=0^{\circ}$ の場合の低次 5 つの固有振動数につ いて曲げ抵抗比 $r$ の影響をみたものが 図一7, $r=10^{-6}$ のときの固有振動数曲線を示したものが 図一8 である. この場合と $k^{2}=900$ の場合である 図一2 とを比較すれ ば,初期水平張力の小さな場合に相当する $k^{2}=4000$ (図 一7）の方が固有振動数 $\omega^{*}$ に及ぼす曲げ抵抗の影響が 大きいことがわかる．各次振動のモード形を調べるとパ ラメーター $k^{2}$ によってはほとんど変化がみられないこ とからこのことは a) で述べたモード形依存性とは異 なるものであると考えられる.つまり，曲げ抵抗の固有 振動数に及ぼす影響は初期水平張力にも依存するといえ る.このことは, 軸引張力が作用する直棒の曲げ剛性が 見かけ上大きくなるといら事実から類推できる結果であ

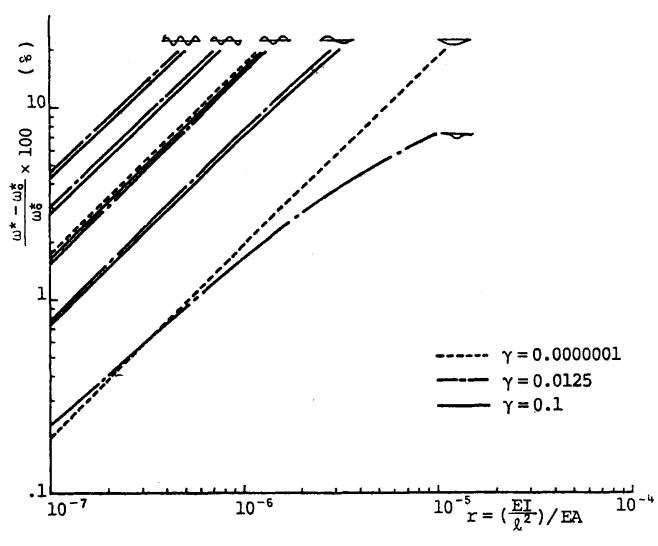

図一7曲け抵抗比に対する固有振動数の変化 $\left(k^{2}=4000, \theta=0^{\circ}\right)$

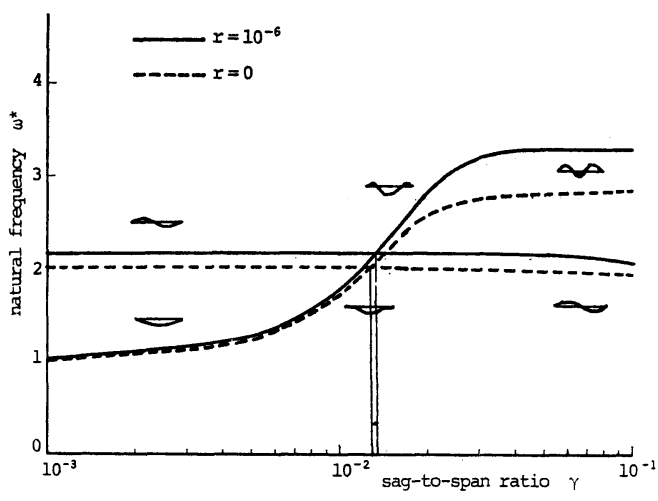

図一8 サグ比に対する固有振動数の変化 $\left(k^{2}=4000, \theta=0^{\circ}\right)$

る.

c）曲げ抵抗比 $r$

完全可接性ケーブルとの比較において曲げ抵抗比 $r$ (=EI/l $\left.l^{2} / E A\right)$ の固有振動数に及ぼす影響を 図一2, 図一 5, 図一7 でみた. ここで示した計算例では $r=10^{-7} \sim$ $10^{-4}$ に対する結果を与えているが，これまでの一般的 な使用例ではさらに小さな $10^{-8}$ 程度の曲げ抵抗比を有 するのではないかと思われる.この $10^{-8}$ という值は PWS 91 について, 曲げ佣性 $E I$ については新家ら ${ }^{4)}$ よる静的曲げ試験結果から得られた值を，スパン長 $l$ に ついては PWS の使用実績 ${ }^{8}$ から類推した值をそれぞれ 用いて概略計算したものである. 種々のケーブルについ ての曲げ剛性の測定值があまりないために一般的な議論 は困難であるが, 過去のケーブル使用例に関しては低次 固有振動に及ぼす曲げ抵抗の影響はそれほど有意でな く，無視できるものと思われる.

なお, 計算例の $r=10^{-7} \sim 10^{-4}$ は実際のケーブルでの 值よりかなり大きな値であるわけで, 特に 図一3, 4, 6 に示した $r=10^{-4}, 10^{-5}$ のケーブルは大変に太短いケー 
ブルとなると思われるが，これはあくまでも完全可接性 ケーブルとの比較において曲げ効果の傾向をはっきり示 すことを考えたためであることを断っておく.

\section{4. 結 論}

ケーブルの最も基本的な動特性としての面内線形自由 振動特性について, 曲げ抵抗比 $r$,つまり曲げ抵抗パラ メーター $E I / l^{2}$ と伸び剛性 $E A$ との比を主とした数值 パラメーター解析を行った. その結果, 次のことが明ら かとなった。

（1）固有振動数に及ぼす曲げ抵抗の影響は振動モー ド形に大きく依存する．曲げ抵抗を考慮したケーブルの 固有振動数は完全可接性ケーブルのそれより大きく, そ の差は高次振動ほど大きい.

（2）完全可捹性ケーブルの場合と同様に，サグ比の 変化によるモード遷移領域が存在する. その領域内の步 グ比を有するケーブルでは曲げ抵抗を考慮したことによ りモード形が有意な変化を示すのに対し，領域外のサグ 比を有するケーブルではほとんど変化しない，その結 果, 固有振動数に及ぼす曲げ効果がサグ比によって異な る.

（3）傾斜ケーブルの場合はモード形の遷移が水平ケ ーブルの場合上異なるため, 固有振動特性に及ぼす曲げ 抵抗の影響も異なる.

（4）曲げ抵抗の固有振動数に及ぼす影響は初期水平 張力にも依存する.

(5) ケーブルの曲げ抵抗の影響が顕著に現われるの は非常に太く短いケーブルであり, 既往のケーブル使用 例に関しては曲げ抵抗の影響は大変小さく, 無視し得 る.

\section{補遺 Galerkin 法による積分項}

$$
\begin{aligned}
I_{1}^{*}= & \int_{0}^{\sigma_{l}}\left(\frac{1}{\xi^{\prime}}+k^{2} \xi^{\prime 2}\right) \cos \frac{i \pi \sigma}{\sigma_{l}} \cos \frac{j \pi \sigma}{\sigma_{l}} d \sigma \cdots \cdots(\mathrm{A} \cdot 1) \\
I_{2} *= & \int_{0}^{\sigma_{l}} \frac{1}{\xi^{\prime \prime 2}+\eta^{\prime 2}}\left\{2 \xi^{\prime \prime} \xi^{\prime \prime \prime}+\eta^{\prime \prime} \gamma^{\prime \prime \prime}\right. \\
& \left.-\frac{2}{\xi^{\prime \prime 2}+\eta^{\prime \prime 2}}\left(\xi^{\prime \prime} \xi^{\prime \prime \prime}+\eta^{\prime \prime} \eta^{\prime \prime \prime}\right) \xi^{\prime \prime 2}\right\} \\
& \cdot \sin \frac{i \pi \sigma}{\sigma_{l}} \cos \frac{j \pi \sigma}{\sigma_{l}} d \sigma \cdots \cdots \cdots \cdots \cdots \cdots(\mathrm{A} \cdot 2) \\
I_{3}^{*}= & \int_{0}^{\sigma_{l}} \frac{1}{\xi^{\prime \prime 2}+\eta^{\prime \prime 2}} \xi^{\prime \prime 2} \cos \frac{i \pi \sigma}{\sigma_{l}} \cos \frac{j \pi \sigma}{\sigma_{l}} d \sigma \cdots \cdots(\mathrm{A} \cdot 3)
\end{aligned}
$$

$$
\begin{aligned}
I_{4} *= & \int_{0}^{\sigma_{l}} \xi^{\prime} \eta^{\prime} \cos \frac{i \pi \sigma}{\sigma_{l}} \cos \frac{j \pi \sigma}{\sigma_{l}} d \sigma \cdots \ldots \ldots \ldots \ldots(\mathrm{A} \cdot 4) \\
I_{5} *= & \int_{0}^{\sigma_{l}} \frac{1}{\xi^{\prime \prime 2}+\eta^{\prime \prime 2}} \xi^{\prime \prime}\left\{\eta^{\prime \prime \prime}-\frac{2}{\xi^{\prime \prime 2}+\eta^{\prime \prime 2}}\left(\xi^{\prime \prime} \xi^{\prime \prime \prime}\right.\right. \\
& \left.\left.+\eta^{\prime \prime} \eta^{\prime \prime \prime}\right) \eta^{\prime \prime}\right\} \sin \frac{i \pi \sigma}{\sigma_{l}} \cos \frac{j \pi \sigma}{\sigma_{l}} d \sigma \cdots \cdots \cdots(\mathrm{A} \cdot 5) \\
I_{6} *= & \int_{0}^{\sigma_{l}} \frac{1}{\xi^{\prime \prime 2}+\eta^{\prime \prime 2}} \xi^{\prime \prime} \eta^{\prime \prime} \cos \frac{i \pi \sigma}{\sigma_{l}} \cos \frac{j \pi \sigma}{\sigma_{l}} d \sigma \cdots(\mathrm{A} \cdot 6) \\
I_{7} *= & \int_{0}^{\sigma_{l}}\left(\frac{1}{\xi^{\prime}}+k^{2} \eta^{\prime 2}\right) \cos \frac{i \pi \sigma}{\sigma_{l}} \cos \frac{j \pi \sigma}{\sigma_{l}} d \sigma \cdots \cdots(\mathrm{A} \cdot 7) \\
I_{8} *= & \int_{0}^{\sigma_{l}} \frac{1}{\xi^{\prime \prime 2}+\eta^{\prime \prime 2}}\left\{\xi^{\prime \prime} \xi^{\prime \prime \prime}+2 \eta^{\prime \prime} \eta^{\prime \prime \prime}\right. \\
& \left.-\frac{2}{\xi^{\prime \prime 2}+\eta^{\prime \prime 2}}\left(\xi^{\prime \prime} \xi^{\prime \prime \prime}+\eta^{\prime \prime} \eta^{\prime \prime \prime}\right) \eta^{\prime \prime 2}\right\} \\
I_{9}^{*}= & \int_{0}^{\sigma_{l}} \frac{1}{\xi^{\prime \prime 2}+\eta^{\prime \prime 2}} \eta^{\prime \prime 2} \cos \frac{i \pi \sigma}{\sigma_{l}} \cos \frac{j \pi \sigma}{\sigma_{l}} d \sigma \cdots \cdots(\mathrm{A} \cdot 9) \\
I_{10} *= & \int_{0}^{\sigma_{l}} \frac{1}{\xi^{\prime \prime 2}+\eta^{\prime \prime 2}} \eta^{\prime \prime}\left\{\xi^{\prime \prime \prime}-\frac{2}{\xi^{\prime \prime 2}+\eta^{\prime \prime 2}}\left(\xi^{\prime \prime} \xi^{\prime \prime \prime}\right.\right. \\
& \left.\left.+\eta^{\prime \prime} \eta^{\prime \prime \prime}\right) \xi^{\prime \prime}\right\} \sin \frac{i \pi \sigma}{\sigma_{l}} \cos \frac{j \pi \sigma}{\sigma_{l}} d \sigma \cdots \cdots \cdots(\mathrm{A} \cdot 10)
\end{aligned}
$$

ここで, $\xi=x_{e} / l, \eta=y_{e} / l$ 核初期座標の無次元量であり, ケーブルの初期形状を表わす．また，ここでの'は無次 元埋込座標 $\sigma\left(=s_{e} / l\right)$ に関する微分を意味する.

\section{参考文献}

1） 山口宏樹・喜田利雄・伊藤 学：ケーブルの動特性に及 ぼす曲げ抵抗の影響, 第 26 回構造工学シンポジウム概要 集, 1980 年 2 月.

2) Ramberger, G. : Die Bestimmung der Normalkräfte in Zuggliedern über ihre Eigenfrequenz unter Berücksichtigung verschiedener Randbedingungen, der Biegesteifigkeit und der Dämpfung, Stahlbau 10/1978.

3) Bauer, F. : Näherungsweise Erfassung der Eigenschwingzahlen eines Spannbandes (flachen Seiles), Bauingenieur, 53, 1978.

4）新家 徹 - 広中邦汎・頭井 洋・西村春久 : 振動法によ るケーブル張力の実用算定式について，土木学会論文報 告集, 第 294 号, 1980 年 2 月.

5）たとえば，崎山 毅 : 初期荷重を有する変断面任意形ア 一于の面内自由振動解析, 上桴学会論文報告集, 第 287 景, 1979 行: 7 月.

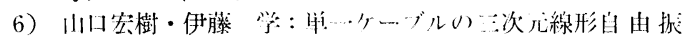
動，十末学全㖮文報告集，第 286 品，1979 件６月．

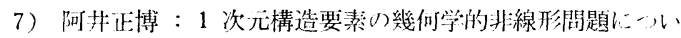
そ, 東京大学学隹論文, 1979 年: 3 月。

8）１１本鋼構造協会技術委員会努全性分科会神構造小委員全 ヶーブル研究班: 構造用ケーブル材料規格, JSSC, Vol. 14, No. 149, 1978 俳 5 月.

(1980.10.8 - 受付) 